\title{
Exocytosis in the Frog Amphibian Papilla
}

\author{
Patricia M. Quiñones ${ }^{1,2}$, Cindy LuU ${ }^{2}$, Felix E. Schweizer ${ }^{2}$, And Peter M. Narins ${ }^{1,3}$ \\ ${ }^{1}$ Department of Integrative Biology and Physiology, University of California, 621 Charles E. Young Drive S., Los Angeles, \\ CA 90095-1606, USA \\ ${ }^{2}$ Department of Neurobiology, David Geffen School of Medicine, UCLA, 650 Charles E. Young Drive S., CHS 63-323, Los Angeles, \\ CA 90095-1763, USA \\ ${ }^{3}$ Department of Ecology and Evolutionary Biology, University of California, 621 Charles E. Young Drive S., Los Angeles, \\ CA 90095-1606, USA
}

Received: 11 April 2011; Accepted: 3 November 2011; Online publication: 29 November 2011

\begin{abstract}
Using whole-cell patch-clamp recordings, we measured changes in membrane capacitance $\left(\Delta C_{\mathrm{m}}\right)$ in two subsets of hair cells from the leopard frog amphibian papilla (AP): the low-frequency $(100-500 \mathrm{~Hz})$, rostral hair cells and the high-frequency $(500-1200 \mathrm{~Hz})$, caudal hair cells, in order to investigate tonotopic differences in exocytosis. Depolarizations of both rostral and caudal hair cells evoked robust $\Delta C_{\mathrm{m}}$ responses of similar amplitude. However, the calcium dependence of release, i.e., the relationship between $\Delta C_{\mathrm{m}}$ relative to the amount of calcium influx $\left(Q_{\mathrm{Ca}}{ }^{2+}\right)$, was found to be linear in rostral hair cells but supra-linear in caudal hair cells. In addition, the higher numbers of vesicles released at caudal hair cell active zones suggests increased temporal precision of caudal hair cell exocytosis. $\Delta C_{\mathrm{m}}$ responses were also obtained in response to sinusoidal stimuli of varying frequency, but neither rostral nor caudal hair cell $\Delta C_{\mathrm{m}}$ revealed any frequency selectivity. While all AP hair cells express both otoferlin and synaptotagmin IV (SytIV), we obtained evidence of a tonotopic distribution of the calcium buffer calretinin which may further increase temporal resolution at the level of the hair cell synapse. Our findings suggest that the low (rostral) and high (caudal) frequency hair cells apply different mechanisms for fine-tuning exocytosis.
\end{abstract}

Present address: Cindy Luu, Keck School of Medicine, University of Southern California, 1975 Zonal Avenue, KAM 100B, Los Angeles, CA 90089-9021, USA.

Correspondence to: Patricia M. Quiñones · Department of Neurobiology, David Geffen School of Medicine - UCLA - 650 Charles E. Young Drive S., CHS 63-323, Los Angeles, CA 90095-1763, USA. Telephone: +1-310-2060448; fax: +1-310-8252224; email: yukiq@ucla.edu
Keywords: auditory hair cells, calcium, exocytosis, capacitance measurements, frequency tuning

\section{INTRODUCTION}

A key function of the vertebrate inner ear is to separate incoming stimuli into frequency components. Several mechanisms have been identified that contribute to this function in auditory systems: besides the mechanical tuning of structures in the inner ear (see Robles and Ruggero 2001), a tonotopic organization of receptors across auditory sensory epithelia and electrical tuning within individual hair cells is a major source of tuning in several species. In addition, tonotopic variation of ion channel properties and expression levels contributes to electrical tuning (reviewed in Fettiplace and Fuchs 1999).

Hair cells, like other tonically active sensory cells, have large synaptic bodies (or ribbons) that tether vesicles in the vicinity of the active zone. The ribbon shape, calcium dependence of exocytosis, vesicle pool replenishment, and synaptic protein expression all vary tonotopically in the cochlea of the gerbil (Johnson et al. 2008, 2009, 2010). In mice, the density of afferent innervation (Meyer et al. 2009) and mRNA expression (Johnson et al. 2010) vary along the tonotopic axis. In turtle, there is a systematic variation in synapse number and free calcium load based on hair cell location along the basilar papilla (Schnee et al. 2005), and in chick, both the calcium channel number and release site area covary based on cell type and position along the basilar papilla (Martinez-Dunst et al. 1997). 
Additional contributors to the tonotopic organization are at the level of the hair cell synapse and exocytosis. In the leopard frog, exocytosis from hair cells of the sacculus is frequency tuned: stimuli at $50 \mathrm{~Hz}$ are more effective than either lower or higher frequency stimuli despite similar calcium entry (Rutherford and Roberts 2006). The high concentration of native calcium buffers that temporally and spatially affect calcium signaling (Roberts 1994) may contribute to differences in the kinetics and amplitude of exocytosis (Edmonds et al. 2000). As these results were obtained from saccular hair cells, believed to be principally substrate-vibration detectors, we asked whether shaping of synaptic release is also present in frog auditory hair cells.

We present capacitance measurements, which have recently been shown to correlate well with neurotransmitter release ( $\mathrm{Li}$ et al. 2009), from hair cells in the amphibian papilla (AP) of the leopard frog, Rana pipiens. This papilla, most sensitive to airborne sounds of frequencies between $\sim 100$ and $\sim 1,200 \mathrm{~Hz}$, is one of two auditory organs found in the frog (Lewis and Narins 1999). The AP is tonotopically organized and its hair cells show a gradation of properties which allows them to be divided into "rostral" and "caudal" populations (Lewis 1976; Simmons et al. 1992, 1994; Smotherman and Narins 1999; Farahbakhsh and Narins 2006). Differences in synapse numbers and ribbon architecture found along the AP (Simmons et al. 1995) suggest unique exocytotic properties of rostral relative to caudal hair cells.

We recorded depolarization-induced capacitance changes in AP hair cells to characterize exocytosis in rostral and caudal hair cells, and test the sensitivity of exocytosis to particular frequencies of stimulation. To gain insight into the role of the ribbon in exocytosis, we explored the hypothesis that synaptic release is different in rostral and caudal hair cells. We looked for differences in the calcium dependence and kinetics of exocytosis as well as the numbers of vesicles released per synapse. In addition, we used immunohistochemistry in the AP to explore the expression of proteins known to affect the calcium dependence of exocytosis.

\section{METHODS}

\section{Semi-intact preparation}

Adult northern leopard frogs ( $R$. pipiens) were sedated, pithed, and decapitated following protocols approved by the UCLA IACCUC. Papillae were dissected and placed on ice for at least $1 \mathrm{~h}$ in a low-calcium $\left(50 \mu \mathrm{M} \mathrm{Ca}^{2+}\right)$ solution $(\mathrm{mM}): 110 \mathrm{NaCl}, 0.4 \mathrm{KCl}, 3 \mathrm{D}-$ glucose, 5 HEPES, $1.6 \mathrm{KOH}$, and $0.05 \mathrm{CaCl}_{2}$, $\mathrm{pH} 7.22$, osmolality 220 mOsm (osmometer model 5520; Wescor Inc., Logan, UT, USA). One papilla was then transferred to a glass-bottom plexiglass recording chamber containing low-calcium solution. The papilla was fastened to the bottom of the recording chamber by fixing both ends with a piece of a coverslip held down by Vaseline. Next, an eyelash was used to make two to four furrows parallel to the tonotopic axis of the sensory epithelium. A small-tipped pipette was then filled with the low-calcium solution and solution was blown across the epithelium to facilitate hair cell separation at the furrow margins. The recording chamber was placed on the stage of an upright microscope (Zeiss Axioskop2; Carl Zeiss Inc., Oberkochen, Germany) equipped with a long-working distance $63 \times 1.0 \mathrm{NA}$ water-immersion objective. A digital camera (Pixelfly; Cooke Corporation, Romulus, MI, USA) attached to the microscope was used to visualize the hair cells on the papilla under IR-DIC illumination. If necessary, hair cells were cleaned with a suction electrode to remove any loose debris from the epithelium. The low-calcium solution was then replaced using gravity perfusion with a perilymph-like standard external recording solution (Bernard et al. 1986).

\section{Whole-cell recordings}

Currents were recorded under whole-cell voltage clamp using an Optopatch amplifier (Cairn Research, Faversham, UK) and a PCI-MIO-16XE-10 data acquisition board (National Instruments, Austin, TX, USA) under the control of software custom written in Labview (National Instruments). Borosilicate glass pipettes (TW150F-4; World Precision Instruments, Sarasota, FL, USA) were fashioned with a programmable pipette puller (model PP-90; Sutter instruments). Electrode resistances typically ranged from 3 to $6 \mathrm{M} \Omega$. Electrodes were coated with an elastomer (R-6101; Dow Corning, Midland, MI, USA) to reduce pipette capacitance. Membrane voltages were corrected for the liquid junction potential of $-13 \mathrm{mV}$ between the intracellular and extracellular solutions (Edmonds et al. 2004). Unless indicated otherwise, waveforms from the electrode were low-pass filtered at $10 \mathrm{kHz}$ and sampled at $20 \mathrm{kHz} . \mathrm{Ca}^{2+}$ currents were leak subtracted using a $\mathrm{P} / 5$ protocol. Given voltage values were not corrected for series resistance errors.

Pipettes were filled with solution containing $(\mathrm{mM})$ : $95 \mathrm{CsCl}, 10$ TEACl, 5 HEPES, $2 \mathrm{MgCl}_{2}$, 2 ATP, 1 GTP, $0.080 \mathrm{Ca}^{2+}$ (calculated free calcium of $12 \mathrm{nM}$ ), and 1 EGTA, pH 7.20, osmolality $200 \mathrm{mOsm}$. The normal external bath solution consisted of $(\mathrm{mM})$ : $96 \mathrm{NaCl}, 2$ $\mathrm{KCl}, 1.8 \mathrm{CaCl}_{2}, 0.7 \mathrm{MgCl}_{2}, 3$ D-glucose, 5 HEPES, and $10 \mathrm{CsCl}, \mathrm{pH} 7.22$, osmolality $220 \mathrm{mOsm}$. For experiments using a low-calcium solution, the $1.8 \mathrm{mM} \mathrm{CaCl}_{2}$ was replaced by $50 \mu \mathrm{M} \mathrm{CaCl}_{2}$. For blocking calcium channels, $50 \mu \mathrm{M} \mathrm{CdCl}_{2}$ was added to the normal external bath solution. 


\section{Capacitance measurements}

Continuous high-resolution capacitance measurements were acquired through admittance analysis with the track-in feature of the Optopatch amplifier (Johnson et al. 2002). Analysis was done using Labview and Origin 7.0 (OriginLab Corporation, Northampton, MA, USA) software.

For capacitance measurements a $1.5-\mathrm{kHz}$ sine-wave voltage, $15 \mathrm{mV}_{\text {rms }}$, was applied over the $\mathrm{DC}$ holding potential of $-85 \mathrm{mV}$. With this protocol, the maximal positive excursion $(-64 \mathrm{mV})$ was below the threshold of calcium channel activation in AP hair cells (Smotherman and Narins 1999; Edmonds et al. 2004). This sine wave was turned off during depolarization and turned back on after return to the holding potential.

Hair cells were subjected to one of two types of depolarizing protocols. The first protocol consisted of DC steps that varied either in amplitude or duration. Capacitance changes were measured in response to 100-ms depolarizing steps to different holding potentials $(-70 \mathrm{mV},-50 \mathrm{mV}, 0 \mathrm{mV}$, or $+20 \mathrm{mV})$. For depolarizing steps to $-50 \mathrm{mV}$ or $-20 \mathrm{mV}$, other step durations were also tested $(-50 \mathrm{mV}-5,10,20,30,50$, 100, 200, 300, 400, 500, 1,000 ms; $-20 \mathrm{mV}-10,20,30$, $50,100,200,300,400,500,800,1,000 \mathrm{~ms})$. In the second protocol, an AC signal (sinusoid with a frequency of $50 \mathrm{~Hz}, 200 \mathrm{~Hz}, 500 \mathrm{~Hz}, 1,000 \mathrm{~Hz}$, or $2,000 \mathrm{~Hz}$ ) was superimposed on a DC voltage step to either $-55 \mathrm{mV}$ or $-50 \mathrm{mV}$. For the DC step to $-55 \mathrm{mV}$, the amplitude of the sinusoidal (AC) signal was $5 \mathrm{mV}_{\mathrm{pp}}$, while for the DC step to $-50 \mathrm{mV}$, a $5 \mathrm{mV}_{\mathrm{pp}}$ or $10 \mathrm{mV}_{\mathrm{pp}}$ AC signal was applied.

\section{Data analysis}

Only cells having series resistances $\leq 30 \mathrm{M} \Omega$ and holding currents $\left(I_{\text {hold }}\right)<250 \mathrm{pA}$ were included in our analysis (higher series resistances preclude accurate measurements of capacitance; most hair cells had $I_{\text {hold }}<100 \mathrm{pA}$ ). For caudal hair cells depolarized to $-20 \mathrm{mV}$, plots were only made for durations for which there were at least five cells recorded. Because large changes in series resistance significantly affect capacitance measurements, data for which $R_{\mathrm{s}}$ changed by more than $10 \%$ were excluded from analysis. Change in capacitance $\left(\Delta C_{\mathrm{m}}\right)$ was calculated by subtracting the mean of a 500 ms period ending immediately prior to the start of the depolarizing pulse (baseline) from the mean capacitance within a $100-\mathrm{ms}$ period starting $50 \mathrm{~ms}$ after the end of the depolarizing pulse (to ensure stability of the changes and no contamination from tail currents). To calculate the number of released vesicles from $\Delta C_{\mathrm{m}}$, we used an estimate of $45 \pm 11 \mathrm{aF} /$ vesicle based on an average frog AP vesicle diameter of $38 \mathrm{~nm}$ (see Li et al. 2009), and a conservative measure of specific capaci- tance of $1 \mu \mathrm{F} / \mathrm{cm}^{2}$ (Gentet et al. 2000). Using a lower value for specific membrane capacitance (Solsona et al. 1998) or a smaller vesicle size (34 nm; Lenzi et al. 1999) would increase our estimates of vesicle numbers but would not fundamentally change our conclusions. Hair cell localization was done immediately following the physiological recordings by taking a $10 \times$ image of the epithelium with the patch pipette in view. The epithelium was divided into two portions (rostral and caudal) using the line where the tectorial curtain would be in the intact epithelium. In general, we recorded from medial-edge hair cells as those were the most easily accessible but did not exclude the few recorded lateral edge hair cells as they were not obvious outliers. Finally, for some figure presentations, we used the box plot method to allow direct visualization of the data. For box plots, the top, horizontal bar of the box represents the 75 th percentile; the line within the box the median (or 50th percentile); and the bottom, horizontal bar of the box represents the 25 th percentile. The maximum and minimum points are defined by the small, horizontal lines that are often extended from the box by a vertical line. The $1 \%$ and $99 \%$ are defined by the crosshairs (x) and the mean is represented by the open squares.

\section{Statistical methods}

All statistics were calculated using SAS 9 (SAS Institute Inc., Cary, NC, USA) and Origin 7.0 (OriginLab Corporation) software. Nested linear and polynomial regressions and nested ANOVA models that incorporated repeated measures were used to determine any differences in release characteristics between rostral and caudal hair cells and to test the dependence of $\Delta C_{\mathrm{m}}$ on stimulus amplitude and duration. Data for duration dependence were fit to a three-group model where an algorithm determined the durations that resulted in the best likelihood fit to the three-group model. The lowest $\log$ likelihood was determined for $-50 \mathrm{mV}$ and the grouping resulted in a short duration group of 5-50 ms, an intermediate duration group of $100-500 \mathrm{~ms}$, and the 1,000 ms data comprised the long duration group. This unbiased approach resulted in the same groupings for the $-20 \mathrm{mV}$ data.

\section{Immunostaining of $A P$}

Animals were placed on ice for 10-20 min prior to pithing and decapitation in accordance with protocols approved by the UCLA IACUC. The otic capsules were opened and perfused with cold $4 \%$ paraformaldehyde (PFA), pH 7.2-7.4. The entire heads were placed in $4 \%$ PFA solution on a shaker. Duration of fixation times varied depending on the antibody used-synaptotag- 
min IV (SytIV): 10 min (Johnson et al. 2010); hair cell soma-1 (HCS-1): 15-30 min (Goodyear et al. 2010); calretinin and calbindin: $2 \mathrm{~h}$. For ears fixed for $2 \mathrm{~h}$, after the first hour of fixation, $800 \mu \mathrm{l}$ of $10 \%$ Triton X-100 was added to the $4 \%$ PFA solution for a $0.2 \%$ Triton X-100 final concentration. Fixation of the frog heads in $4 \%$ PFA and $0.2 \%$ Triton X-100 proceeded for another hour. After fixation, frog heads were rinsed three times for $15 \mathrm{~min}$ each with $0.1 \mathrm{M}$ phosphate buffered saline (PBS) (Cellgro, Mediatech, Inc., VA, USA). Ears were then dissected out in 0.1 M PBS, sacculi and APs were removed, and the APs were dissected to expose the sensory epithelia.

To reduce nonspecific labeling, APs were placed for $2 \mathrm{~h}$ at room temperature in an initial blocking solution (PBS with 5\% normal goat serum and $0.1 \%$ triton X-100). The initial blocking was modified for the SytIV antibody (see Johnson et al. 2010). Following initial blocking, specimens were placed overnight at $4^{\circ} \mathrm{C}$ in a second solution containing the initial blocking solution at a dilution of $1: 10$ and primary antibodies at the following dilutions: rabbit anti-calbindin polyclonal (Chemicon, Temecula, CA, USA) and mouse anti-calretinin polyclonal (Chemicon) both at 1:500; mouse anti-parvalbumin (P3088 Sigma) at 1:2,000, mouse anti-synaptotagmin IV monoclonal (Abcam, ab57473 - gift from Dr. M. Knipper) at 1:50, and mouse monoclonal anti-HCS-1 (Goodyear et al. 2010; courtesy of Dr. J. Corwin) at 1:2,000. Specimens were then rinsed three times for $10 \mathrm{~min}$ in PBS, and incubated with a mixture of goat Alexa Flour 488-conjugated anti-rabbit IgG and goat Alexa Flour 568-conjugated anti-mouse IgG (Invitrogen, Carlsbad, CA, USA) at 1:500 dilution for $2 \mathrm{~h}$ at room temperature. Specimens were re-rinsed three times for $10 \mathrm{~min}$ in PBS and mounted with Vectashield Hardset mounting medium containing DAPI (Vector Laboratories, Inc., Burlingame, CA, USA) for fluorescent and confocal microscopy. For negative controls, primary antibodies were omitted. For calbindin/calretinin experiments, sacculi were stained as the APs described above and used as positive controls.

\section{Image capture and analysis}

Confocal image stacks were acquired using a Zeiss upright LSM 710 confocal microscope, Zen software, and Nomarski sampling for the $488 \mathrm{~nm}$ laser line. A plan-neofluar $10 \times$ objective $(\mathrm{NA}=0.3)$ was used for low magnification images and a plan-apochromat $63 \times$ objective (NA=1.2; water) was used for high magnification images. Confocal stack image preparation and analysis were done using Volocity software (Perkin Elmer, Waltham, MA, USA). To quantify differences in immunostaining intensity, regions of interest in the caudal and rostral regions were selected on $10 \times$ images and the mean intensities calculated. Resampling statistics (bootstrapping) was used to determine the significance of intensity differences and intensity ratios.

\section{RESULTS}

AP hair cell exocytosis is a calciumand voltage-dependent process

Chemical neurotransmission at ribbon synapses, like at other synapses, involves a presynaptic depolarization that results in the opening of voltage-gated calcium channels, leading to calcium influx into the presynaptic terminal that triggers vesicle fusion and neurotransmitter release. To confirm that hair cell exocytosis in the amphibian papilla (AP) follows this classic pattern and to further probe the calcium dependence of this system, we presented rostral (low frequency) and caudal (high frequency) hair cells with step depolarizations and measured the resulting inward current and the change in cell membrane capacitance $\left(\Delta C_{\mathrm{m}}\right)$. Rostral hair cell baseline capacitance ranged from $6 \mathrm{pF}$ to $24 \mathrm{pF}$ (mean $=14 \pm 3 \mathrm{pF}, n=$ 214 cells) and differed significantly $(p<0.01)$ from caudal hair cell baseline capacitance which ranged from $6 \mathrm{pF}$ to $15 \mathrm{pF}$ (mean $=10 \pm 2 \mathrm{pF}, n=114$ cells). The range in baseline capacitance overlaps measurements obtained by Smotherman and Narins (1999) who divided the AP into three parts along its tonotopic axis: rostral $(12-16 \mathrm{pF})$, middle or medial $(8-12 \mathrm{pF})$, and caudal (4-8 pF). Figure 1 shows examples of two voltage-clamp recordings from hair cells in the rostral (Fig. 1A) and caudal (Fig. 1B) portion of the AP, respectively. In both hair cells, a 100-ms depolarizing voltage command to $-20 \mathrm{mV}$ elicited an inward current largely due to calcium influx since other conductances were blocked (see "Methods" and Fig. 2). The current was integrated to quantify the mean calcium charge influx $\left(Q_{\mathrm{Ca}}{ }^{2+}\right)$. The $Q_{\mathrm{Ca}}{ }^{2+}$ values were $17.5 \pm 1.6 \mathrm{pC}(n=19)$ and $14.5 \pm$ 1.7 pC $(n=12)$ for rostral and caudal hair cells, respectively. The depolarizations also resulted in a cell membrane capacitance increase of $25.7 \pm 7.3 \mathrm{fF}$ for rostral $(n=19)$ and $27.0 \pm 9.2 \mathrm{fF}(n=12)$ for caudal hair cells, while the series resistance remained unchanged $\left(\Delta R_{\mathrm{s}}=3.9 \pm 58.7 \mathrm{k} \Omega\right.$; for all cells combined; see "Methods").

To test whether $\Delta C_{\mathrm{m}}$ depends on calcium influx in AP hair cells, calcium currents were either blocked by adding $50 \mu \mathrm{M}$ cadmium to the external solution or by lowering external calcium to $50 \mu \mathrm{M}$ (Fig. 2). Cadmium decreased the peak inward calcium currents $\left(I_{\max }\right)$ by an average of $65 \%$ from $-227 \pm 32 \mathrm{pA}$ to $-79 \pm 16$ (Fig. 2A, note that currents shown are not 
A

Rostral

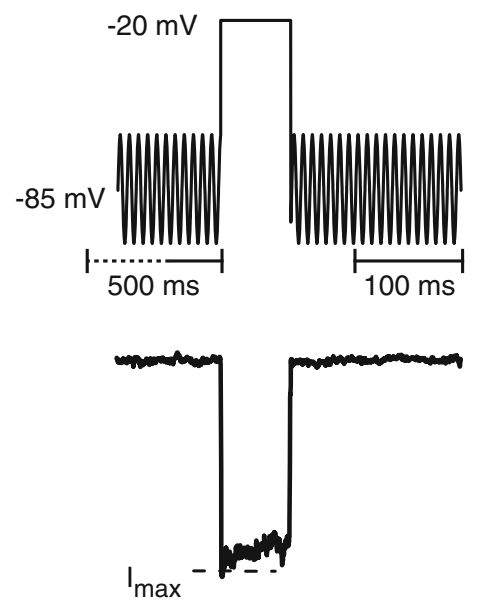

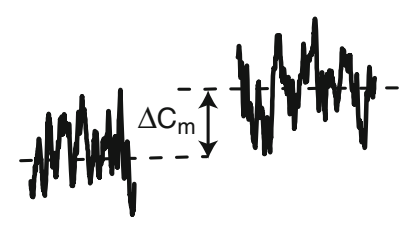

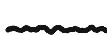

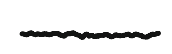

B

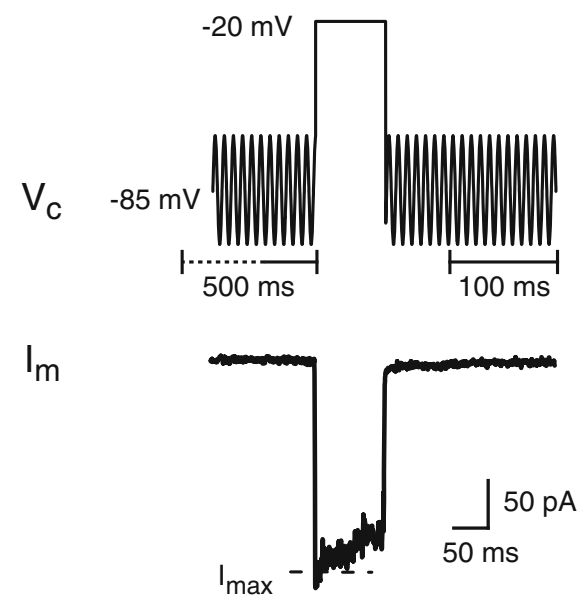

$\mathrm{C}_{\mathrm{m}}$

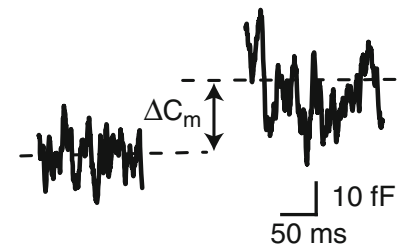

$\mathrm{R}_{\mathrm{S}}$

\section{Caudal}

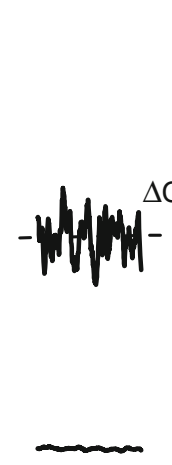

leak-subtracted). The integrated charge, $Q_{\mathrm{Ca}}{ }^{2+}$, was reduced by $71 \%$ from $44.6 \pm 7.4 \mathrm{pC}$ to $12.9 \pm 4.8 \mathrm{pC}$ and $\Delta C_{\mathrm{m}}$ was reduced by $71 \%$ from $26.0 \pm 4.3 \mathrm{fF}$ to $7.4 \pm 2.3 \mathrm{fF}$ (Fig. 2B, $n=6$ ). Similar results were obtained by perfusion of low calcium solution (Fig. 2B, control$n=9, \mathrm{Cd}^{2+}-n=6$, low $\mathrm{Ca}^{2+}-n=3$ ). Thus, either blocking calcium entry or lowering its external concentration reduced the inward current, $Q_{\mathrm{Ca}}{ }^{2+}$ and $\Delta C_{\mathrm{m}}$, demonstrating that $C_{\mathrm{m}}$ increases depend on calcium influx.

To determine the voltage dependence of exocytosis, hair cells were depolarized for $100 \mathrm{~ms}$ from rest $(-85 \mathrm{mV})$ to four voltage command potentials: $-70,-50,-20$, and $0 \mathrm{mV}$. The capacitance increase $\left(\Delta C_{\mathrm{m}}\right)$ and the calcium influx increased with increasing depolarizations up to $-20 \mathrm{mV}$ and then substantially decreased (Fig. 3A). This revealed similar voltage dependence of $\Delta C_{\mathrm{m}}$ and $Q_{\mathrm{Ca}}{ }^{2+}$ in rostral and caudal hair cells (nested polynomial regression, $p>0.9$; Fig. $3 \mathrm{~A}$ ). However, plotting $\Delta C_{\mathrm{m}}$ as a function of the total calcium influx (Fig. 3B, C) reveals an intriguing difference between rostral and caudal hair cells. In rostral hair cells, the relationship between $\Delta C_{\mathrm{m}}$ and the total inward calcium flux appears linear (Fig. 3B), while for the caudal hair cells this relationship appears nonlinear (Fig. 3C). To determine whether the
FIG. 1. Depolarization of both rostral (A) and caudal (B) AP hair cells elicited inward currents and concomitant changes in capacitance. The top traces represent the hair cell's command voltage $\left(V_{c}\right)$. The brief depolarization (100 ms) elicited an inward current $\left(I_{\mathrm{m}}\right)$. The cell's capacitance $\left(C_{\mathrm{m}}\right)$ and series resistance $\left(R_{\mathrm{s}}\right)$ are shown before and after depolarization. The change in capacitance $\left(\Delta C_{\mathrm{m}}\right)$ was calculated as the difference between the mean capacitance (dashed lines) before and after depolarization of the cell. The time brackets underneath the commandvoltage trace indicate the time windows over which the mean capacitance before and after the depolarizing step were calculated. $I_{\mathrm{m}}$ traces have been leak subtracted. two relationships were indeed different, the following equation was fit to the mean values of both datasets:

$$
\Delta C_{\mathrm{m}}=A\left(Q_{\mathrm{Ca}^{2+}}\right)^{N}
$$

The values obtained from the equation fits were as follows: rostral- $A=0.5 \pm .75 \mathrm{fF} /(\mathrm{pC})^{N} ; N=1.4 \pm 0.5 ; R^{2}=$ $0.89 ; n=4$; caudal $-A=0.02 \pm 0.03 \mathrm{fF} /(\mathrm{pC})^{N} ; N=2.7 \pm 0.7$; $R^{2}=0.97 ; n=4$. This indicates a small but statistically significant difference in the calcium dependence of exocytosis (Fig. 3B, C). Rostral hair cells exhibit a nearly linear calcium dependence while for caudal hair cells the power was $\sim 3$, suggesting a calcium cooperativity of at least 3 or 4 (Dodge and Rahamimoff 1967).

\section{AP hair cell exocytosis has multiple kinetic components}

The kinetics of exocytosis were determined using two protocols that differed in the amplitude of the depolarizing voltage command step size (to $-50 \mathrm{mV}$ or $-20 \mathrm{mV}$ ). As expected for non-inactivating calcium channels, the total calcium influx increased linearly 
A Normal External

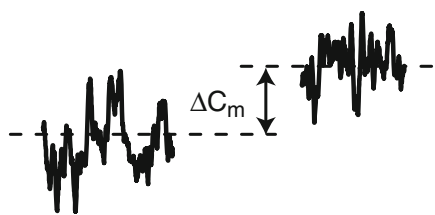

$\mathrm{C}_{\mathrm{m}}$
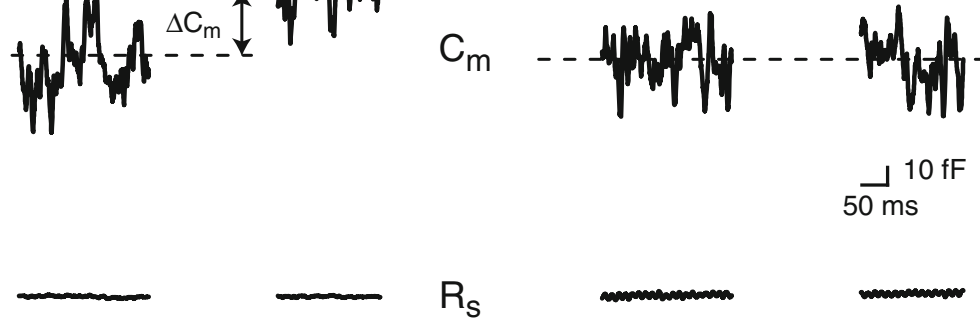

$R_{S}$

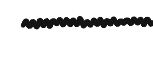

$\underset{50 \mathrm{~ms}}{ل 200 \mathrm{k} \Omega}$

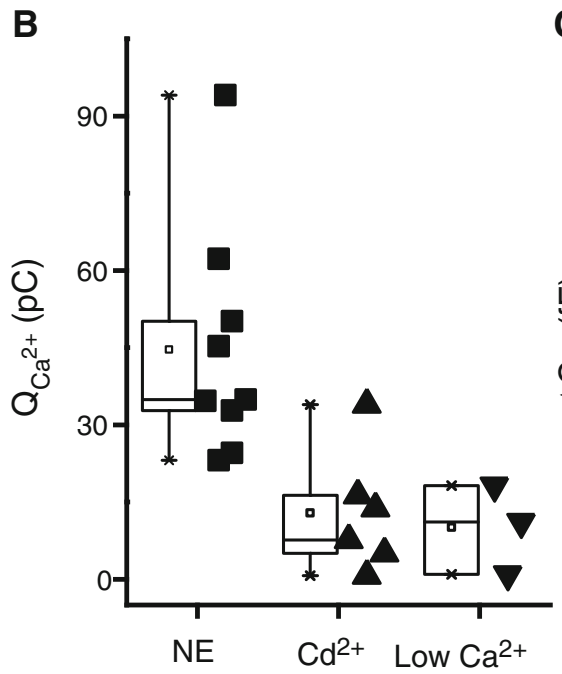

C

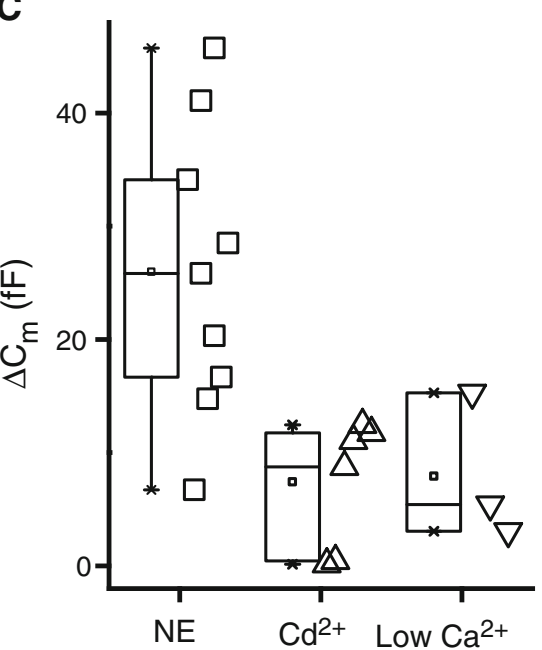

FIG. 2. Exocytosis is calcium dependent. A Sample traces from a rostral hair cell held at $-85 \mathrm{mV}$ and then depolarized to $-50 \mathrm{mV}$ for $200 \mathrm{~ms}$ in control solution (left panel) and then switched to a cadmium $(50 \mu \mathrm{M})$ external solution (right panel). Note: the $I_{\mathrm{m}}$ trace in this figure is not leak subtracted. B Box and scatter plot of the total calcium influx calculated as the integral of the current $\left(Q_{\mathrm{Ca}}{ }^{2+}\right)$ for control normal external ( $N E$, filled squares), cadmium $\left(\mathrm{Cd}^{2+}\right.$, filled triangles), and low calcium (Low $\mathrm{Ca}^{2+}$, filled inverted triangles) solutions. Hair cells were obtained from the rostral portion of the amphibian papilla. Perfusion of cadmium reduced $\mathrm{QCa}^{2+}$ by $71 \%$ while low external calcium resulted in a $77 \%$ reduction. $\mathbf{C}$ Box and scatter plot for $\Delta C_{\mathrm{m}}$ (same experiments as in B). Perfusion changes from $\mathrm{NE}$ (open squares) to $\mathrm{Cd}^{2+}$ (open triangles) resulted in a $71 \%$ decrease in $\Delta C_{\mathrm{m}}$. A similar effect is elicited when replacing the normal external solution with a low-concentration calcium $(50 \mu \mathrm{M})$ solution $(69 \%)$. Control: $n=9$, cadmium: $n=6$, low calcium: $n=3$. with the duration of the stimulus for depolarization to either -50 or $-20 \mathrm{mV}$ in both rostral and caudal hair cells (Fig. 4A, B inset). For the depolarizing steps to $-50 \mathrm{mV}$ (5-1,000 $\mathrm{ms}$ durations), we found no differences in the kinetics of rostral and caudal hair cells (Fig. $4 \mathrm{~A})$. The $\Delta C_{\mathrm{m}}$ was multiphasic and could be broken into three time-dependent components (see "Methods" and "Discussion"): up to, and including, $50 \mathrm{~ms}, 100-500 \mathrm{~ms}$, and 1,000 ms.

The magnitude of the first kinetic component was calculated as the average of responses at 30 and $50 \mathrm{~ms}$, where the magnitude of the $\Delta C_{\mathrm{m}}$ leveled off for both rostral and caudal hair cells, yielding a $\Delta C_{\mathrm{m}}$ of $3.2 \pm 0.5 \mathrm{fF}$ (corresponding to the net fusion of $\sim 71$ vesicles assuming a single vesicle capacitance of $45 \mathrm{aF}$; see "Methods"). Because there are approximately 16 active zones in rostral hair cells and only six in caudal hair cells (Simmons et al. 1995), this means that per synaptic site, rostral hair cells are releasing fewer $(\sim 4)$ vesicles than caudal $(\sim 11)$ hair cells. Analysis of the other kinetic components revealed only a trend toward higher caudal release that was not significant. We also investigated exocytotic efficiency $\left(\Delta C_{\mathrm{m}} / Q_{\mathrm{Ca}}{ }^{2+}\right)$ but again did not observe a statistically significant effect.

With depolarizations to $-20 \mathrm{mV}$, hair cells exhibit the largest calcium influxes and capacitance increases (see Fig. 3A). When rostral and caudal hair cells were depolarized to a command voltage of $-20 \mathrm{mV}$ for durations between 10 and $1,000 \mathrm{~ms}$, we noted the same three kinetic components of exocytosis as seen at $-50 \mathrm{mV}$ (Fig. 4B cf. Fig. 4A). During the second component, between $100 \mathrm{~ms}$ and $500 \mathrm{~ms}, \Delta C_{\mathrm{m}}$ tended to decrease with increasing durations of the depolarizing step, an observation that was consistent over many preparations. This consistent but unexplained decrease made it necessary to analyze the data in three kinetic components rather than using a more conventional approach. In caudal hair cells, long 
A
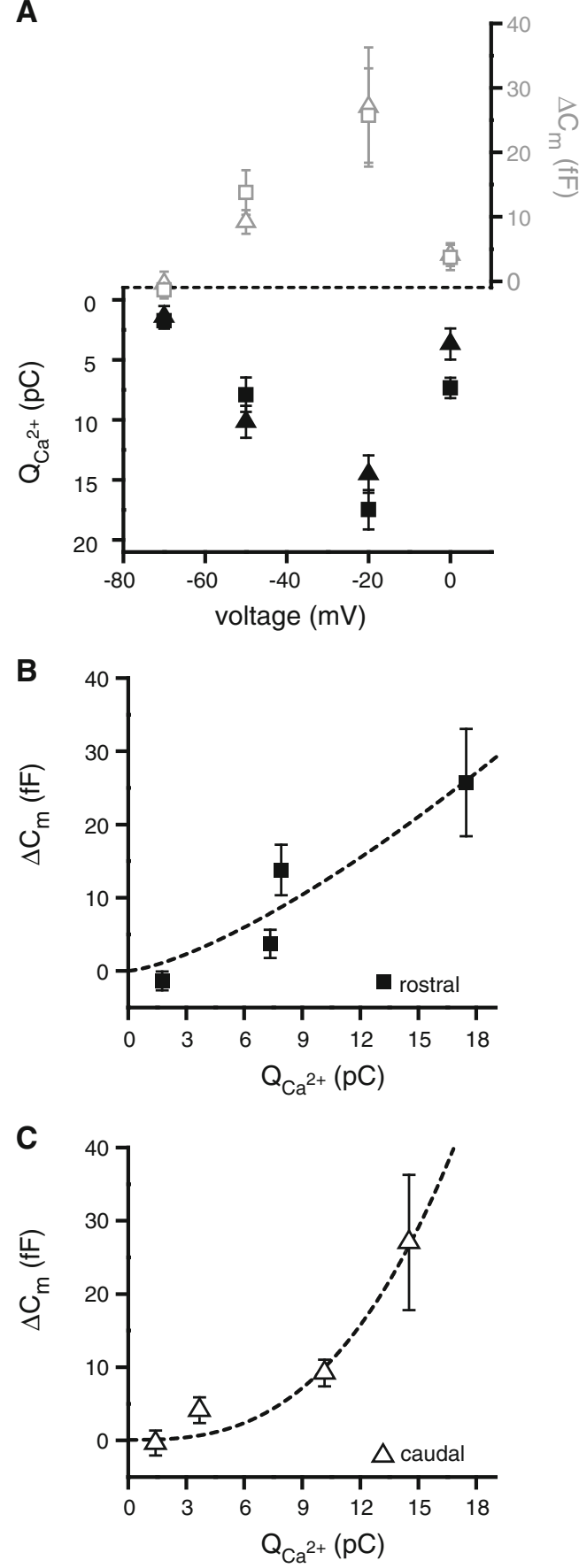

FIG. 3. Voltage dependence of exocytosis is similar in rostral and caudal hair cells. A Mean calcium influx $Q_{\mathrm{Ca}}{ }^{2+}$ (black symbols) and capacitance change $\Delta C_{\mathrm{m}}$ (gray symbols) for both rostral (squares) and caudal (triangles) hair cells plotted as a function of depolarization voltage. $\Delta C_{\mathrm{m}}$ shows a linear dependence of exocytosis on calcium for rostral (B) but not for caudal (C) hair cells. A power function $\left[\Delta C_{\mathrm{m}}=A\left(Q_{\mathrm{Ca}}{ }^{2+}\right)^{N}\right]$ was fit to the data and is shown superimposed as a dotted line (rostral- $A=0.5 \pm .75 ; N=1.4 \pm 0.5 ; R^{2}=0.89$; caudal$A=0.02 \pm 0.03 ; N=2.7 \pm 0.7 ; R^{2}=0.97$.

depolarizations to $-20 \mathrm{mV}$ also induced a conductance change upon repolarization of the membrane to rest $(-85 \mathrm{mV})$, possibly due to the re-activation of
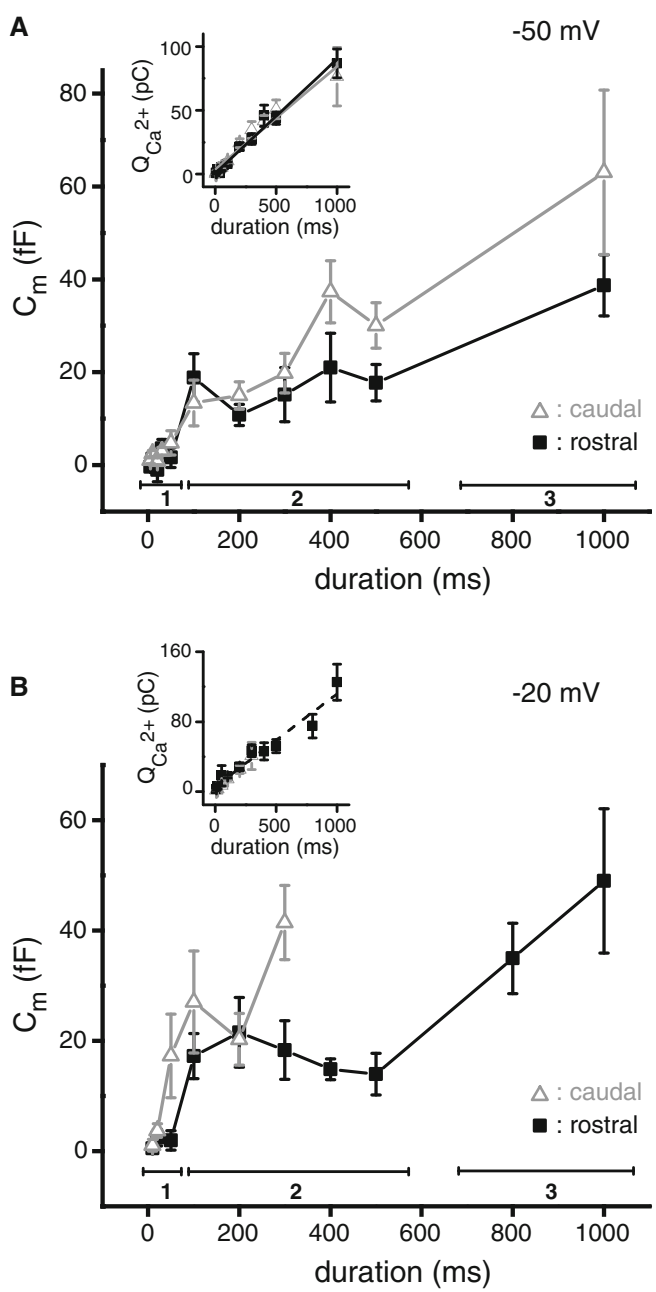

FIG. 4. Kinetics of exocytosis are similar for small and large depolarizations. A Means of capacitance change as a function of the length of the depolarization for rostral (black filled squares) and caudal (gray open triangles) hair cells. Depolarization was to $-50 \mathrm{mV}$. A three-component model was fitted to the data to quantify different kinetic components: a fast component which saturated by $50 \mathrm{~ms}$ (first group, bar 1), an intermediate component for durations between 100 and $500 \mathrm{~ms}$ (second group, bar 2), and a final long duration group at 1,000 ms (third group, bar 3 ). The inset shows the corresponding mean calcium charge influx for these recordings. These data were fitted with linear equations $Q_{\mathrm{Ca}}{ }^{2+}=A+B t$ [rostral (black line)— $A=0.8 \pm 1.3 ; B=0.09 \pm 0.004 ; R^{2}=0.98$; caudal (gray line) $\left.-A=3.6 \pm 2.0 ; B=0.08 \pm 0.01 ; R^{2}=0.96\right]$. B For rostral hair cells (black filled squares), depolarizations of varying duration to $-20 \mathrm{mV}$ elicited the same time course and multiphasic change in capacitance as seen for depolarizations to $-50 \mathrm{mV}$. $\Delta C_{\mathrm{m}}$ could only be measured in caudal hair cells (gray open triangles) for durations less than $300 \mathrm{~ms}$. As in (A), the inset gives the corresponding mean calcium influx. Linear fit to the data from rostral hair cells is $Q_{\mathrm{Ca}}{ }^{2+}=A+B t$ with $A=6.2 \pm 4.0 ; B=0.11 \pm 0.01, R^{2}=0.95$.

the inward rectifier $\left(I_{\mathrm{kl}}\right)$ (Smotherman and Narins 1999) which persisted for hundreds of milliseconds. Since this long-lasting conductance change affects capacitance measurements, we excluded $\Delta C_{\mathrm{m}}$ measurements for depolarizations longer than $300 \mathrm{~ms}$. It 
therefore remains to be determined whether rostral and caudal hair cell exocytosis in response to prolonged depolarizations to $-20 \mathrm{mV}$ is similar.

Sinusoidal stimulation does not reveal a frequency selectivity of exocytosis in AP hair cells

Frog saccular hair cells have been reported to show more robust exocytosis in response to sinusoidal stimulation at their resonant frequency of $50 \mathrm{~Hz}$ than at either 5 or $200 \mathrm{~Hz}$ (Rutherford and Roberts 2006). Since in the AP, rostral hair cells are sensitive to 100 $500 \mathrm{~Hz}$ and caudal hair cells are tuned to $500-1,200 \mathrm{~Hz}$, we asked whether exocytosis in these hair cells is tuned to these frequency ranges. For this, sinusoidal stimuli of different frequencies $(50,200,500,1,000$, and $2,000 \mathrm{~Hz}$ ) were used to stimulate exocytosis in each cell type. A sine wave of $5 \mathrm{mV}_{\mathrm{pp}}$ or $10 \mathrm{mV}_{\mathrm{pp}}$ amplitude was superimposed on a 1,000-ms-long DC depolarization from $-85 \mathrm{mV}$ to either $-55 \mathrm{mV}$ or $-50 \mathrm{mV}$. All protocols elicited robust calcium influxes and capacitance increases. The total amount of calcium entry for a given amplitude and DC depolarization was constant and independent of the sine wave frequency. The $\Delta C_{\mathrm{m}}$ responses were also independent of the sine-wave frequency for both rostral and caudal hair cells (Fig. $5 \mathrm{~A}, 5 \mathrm{mV}_{\mathrm{pp}}$ around $-55 \mathrm{mV}$; Fig. $5 \mathrm{~B}, 10 \mathrm{mV}_{\mathrm{pp}}$ around $-50 \mathrm{mV}$; Fig. $5 \mathrm{C},-5 \mathrm{mV}_{\mathrm{pp}}$ around $-50 \mathrm{mV}$ ). For a $5 \mathrm{mV}_{\mathrm{pp}}$ sine wave around $-55 \mathrm{mV}$ and a $10 \mathrm{mV}_{\mathrm{pp}}$ sine wave around $-50 \mathrm{mV}$, there was a trend for caudal hair cells to display on average larger $\Delta \mathrm{C}_{\mathrm{m}}$ responses (Fig. 5A, B) and, surprisingly, the smallest $\Delta \mathrm{C}_{\mathrm{m}}$ responses were observed for the $5 \mathrm{mV}_{\mathrm{pp}}$ sine wave at $-50 \mathrm{mV}$. In summary, despite intriguing tonotopic trends, we did not observe any frequency tuning of exocytosis in hair cells of the amphibian papilla.

Otoferlin and synaptotagmin IV are present in frog AP hair cells

We observe a power relationship between calcium entry and exocytosis in caudal hair cells while in rostral hair cells this relationship is linear (Fig. 3C, B, respectively). In the mammalian cochlea, expression of otoferlin (Beurg et al. 2010) and SytIV (Johnson et al. 2010) have been proposed to be responsible for the developmental linearization of the calcium dependence of exocytosis in auditory hair cells. Thus, we were interested in testing whether the observed difference in calcium dependence in the frog ear could be correlated with differences in the expression pattern of these two proteins along the tonotopic axis in the amphibian papilla. For this, we used the haircell-specific HCS-1 antibody (Gale et al. 2000) that has been shown to specifically label otoferlin (Goodyear
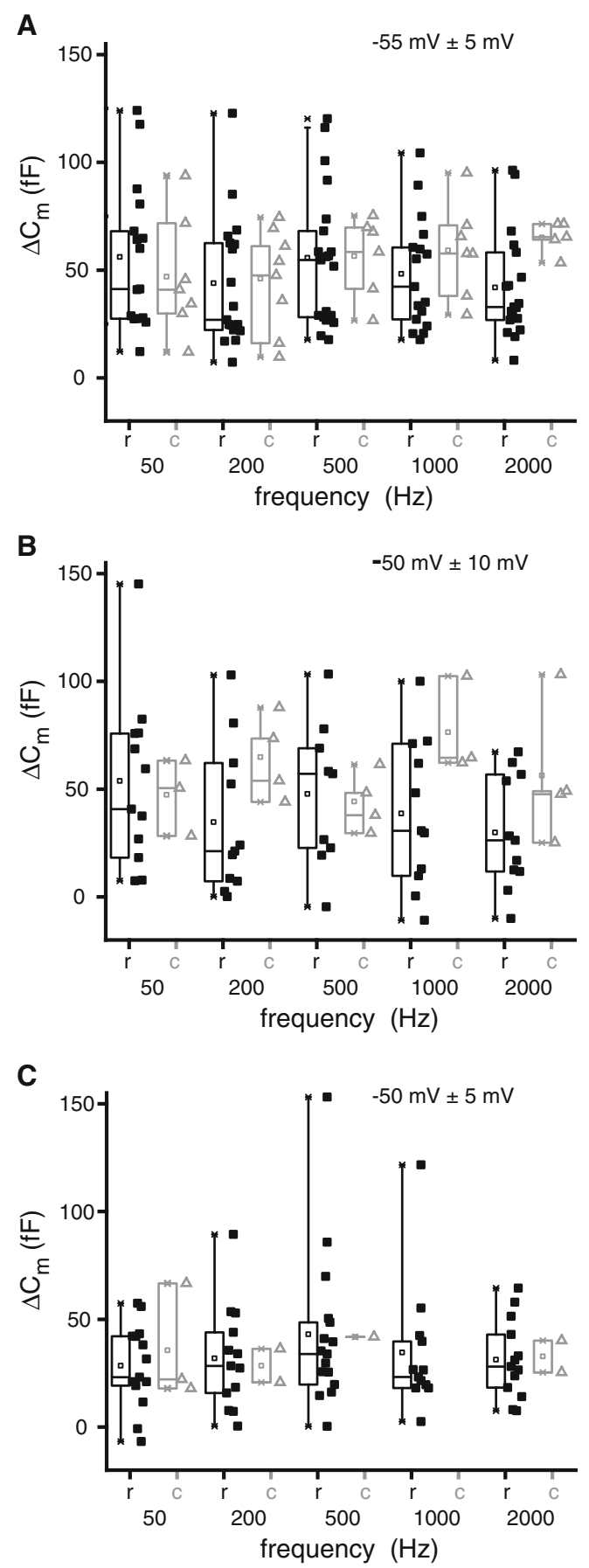

FIG. 5. Sinusoidal stimulation does not reveal tuning of exocytosis. $\Delta C_{\mathrm{m}}$ box and scatter plots at each test frequency for rostral (squares) and caudal hair cells (triangles). A Hair cells were depolarized to $-55 \mathrm{mV}$ and a 5-mV peak-to-peak sinusoid of varying frequency was applied around the depolarizing pulse. B Same as in (A) except cells were depolarized to $-50 \mathrm{mV}$ with a superimposed $10-\mathrm{mV}$ peak-to-peak sinusoid. C Same as in (A) except cells were depolarized to $-50 \mathrm{mV}$ with a superimposed 5-mV peak-to-peak sinusoid.

et al. 2010). All hair cells in the frog AP stained positive for HCS-1, but we did not detect any difference in labeling intensity along the tonotopic 
axis $\left(\mathrm{p}>0.1\right.$; Fig. $\left.6 \mathrm{~B}, \mathrm{C}^{\prime}, \mathrm{D}^{\prime}, \mathrm{E}^{\prime}\right)$, even at higher dilutions of the HCS-1 antibody $(1: 2,000)$ than are commonly used (Gale et al. 2000; Goodyear et al. 2010). We next labeled the epithelium using the SytIV antibody that had been characterized in the mammalian cochlea (Johnson et al. 2010). Again, this antibody robustly labeled all hair cells, but failed to reveal an expression gradient along the tonotopic axis of the AP $\left(\mathrm{p}>0.4\right.$; Fig. $\left.7 \mathrm{~B}, \mathrm{C}^{\prime}, \mathrm{D}^{\prime}, \mathrm{E}^{\prime}\right)$. While the antibody against otoferlin has been shown to be highly specific in frog (Goodyear et al. 2010), it seems possible that the SytIV antibody, while specific in rodents (Johnson et al. 2010), does crossreact with other isoforms in frog, thereby obscuring any SytIVspecific gradients. Obviously, a negative result always has more than one interpretation, but it seems unlikely that differences in expression of otoferlin or SytIV between caudal and rostral hair cells explain the observed differences in calcium dependency.

\section{Differences in the intrinsic calcium buffers} along the AP tonotopic axis

We also investigated the expression of fast, mobile calcium-binding proteins (CaBPs) since they are known to affect calcium signaling in the basolateral membrane of hair cells where synaptic transmission occurs (Roberts 1993; Edmonds et al. 2000). We find that calbindin (Figs. 7A, C, D, E and 8A, C, D, E) as well as parvalbumin (data not shown) are present in
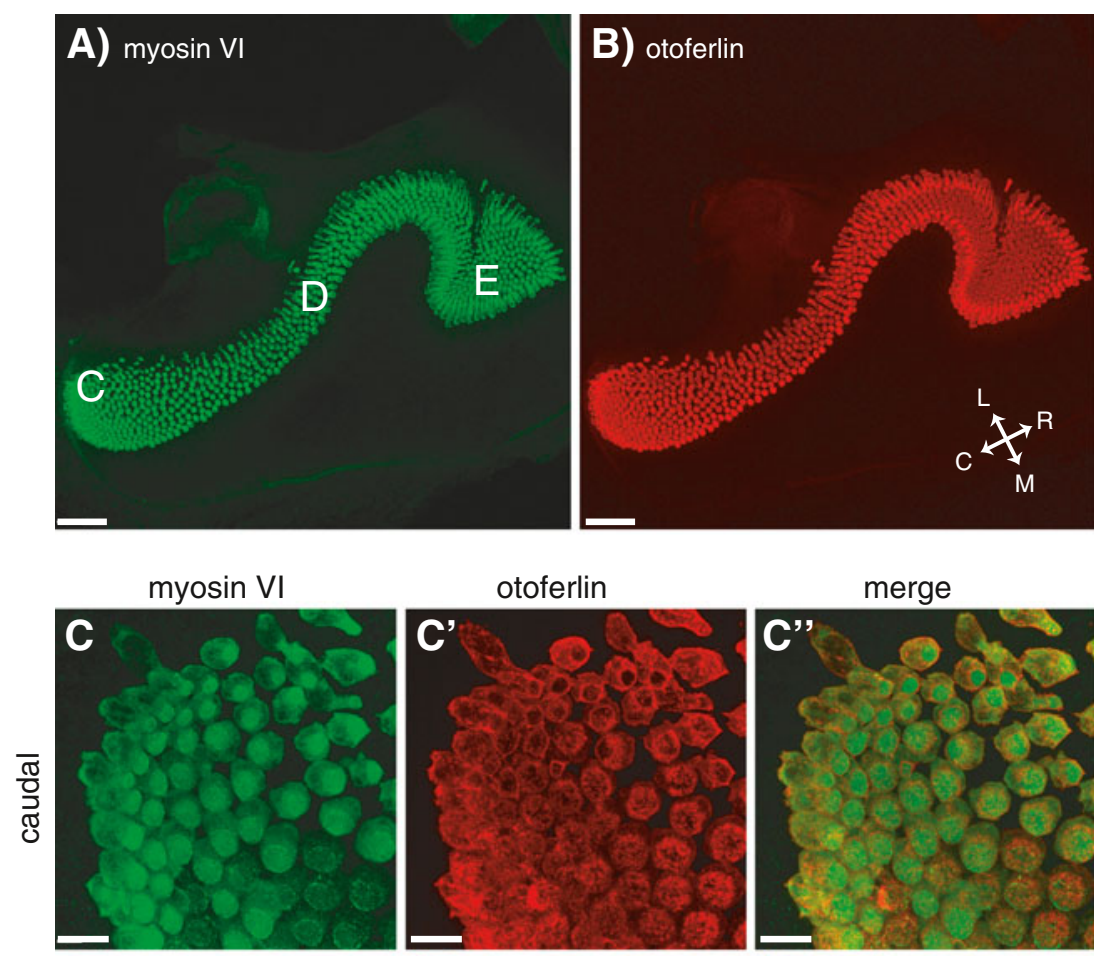

otoferlin
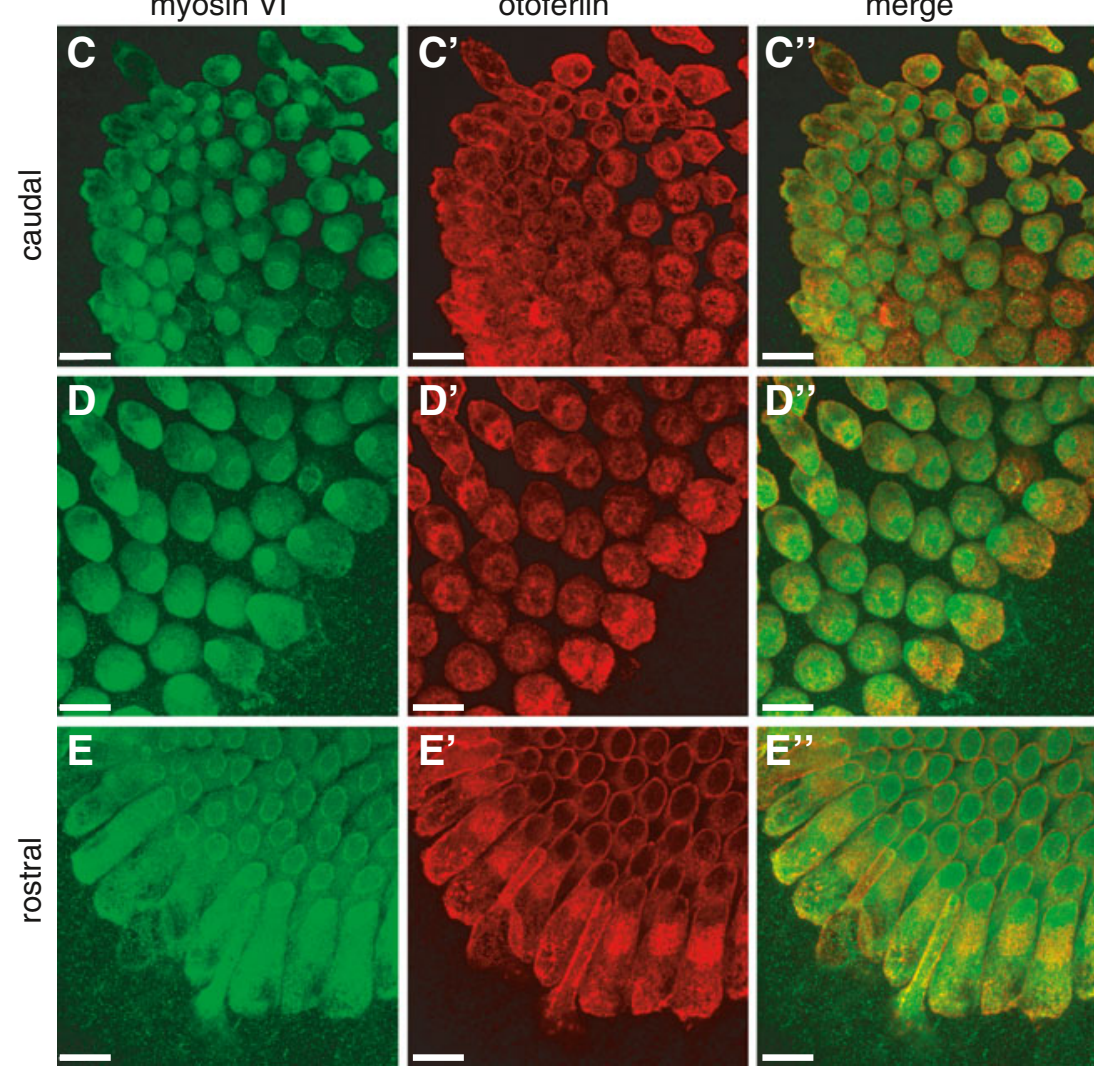

FIG. 6. Otoferlin is present in all AP hair cells. A $10 \times$ image of the AP that has been stained for myosin $\mathrm{VI}(\mathbf{A})$ and otoferlin (B). The orientation of the papilla is indicated by the inset in $(\mathbf{B})$, where $C$ caudal, $R$ rostral, $M$ medial, and $L$ lateral. C $63 \times$ images of the caudal region of the AP showing labeling of myosin $\mathrm{VI}(\mathbf{C})$, otoferlin $\left(\mathbf{C}^{\prime}\right)$ and their merged image $\left(\mathbf{C}^{\prime \prime}\right)$. $\mathbf{D}, \mathbf{D}^{\prime}, \mathbf{D}^{\prime \prime}$ as in $(\mathbf{C})$, but from the medial portion of AP. E, $\mathbf{E}^{\prime}, \mathbf{E}^{\prime \prime}$ as in $(\mathbf{C})$ but from the rostral portion of the AP. The approximate location for these higher magnification images are indicated in (A). Scale bars: $96 \mu \mathrm{m}(\mathbf{A}, \mathbf{B}) ; 14 \mu \mathrm{m}(\mathbf{C}-\mathbf{E})$. 

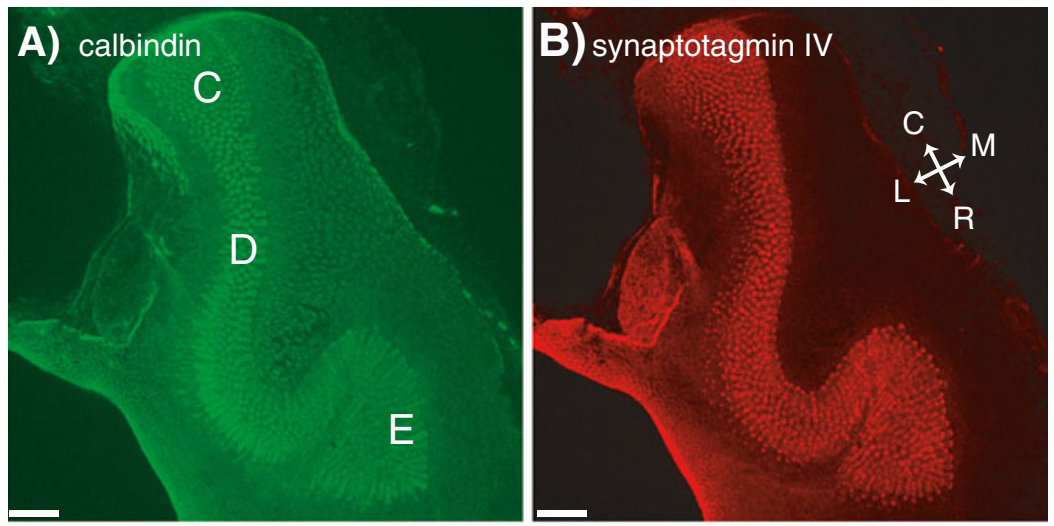

FIG. 7. Synaptotagmin IV is present in hair cells of the frog AP. The general layout of the figure is the same as in Figure 6. Low magnification (10×) images of the AP showing staining for calbindin (A) and synaptotagmin IV (B). Higher magnification $(63 \times)$ images for three different locations along the AP are given in (C), (D), and (E). Scale bars: $90 \mu \mathrm{m}(\mathbf{A}, \mathbf{B})$; $14 \mu \mathrm{m}(\mathbf{C}-\mathbf{E})$.
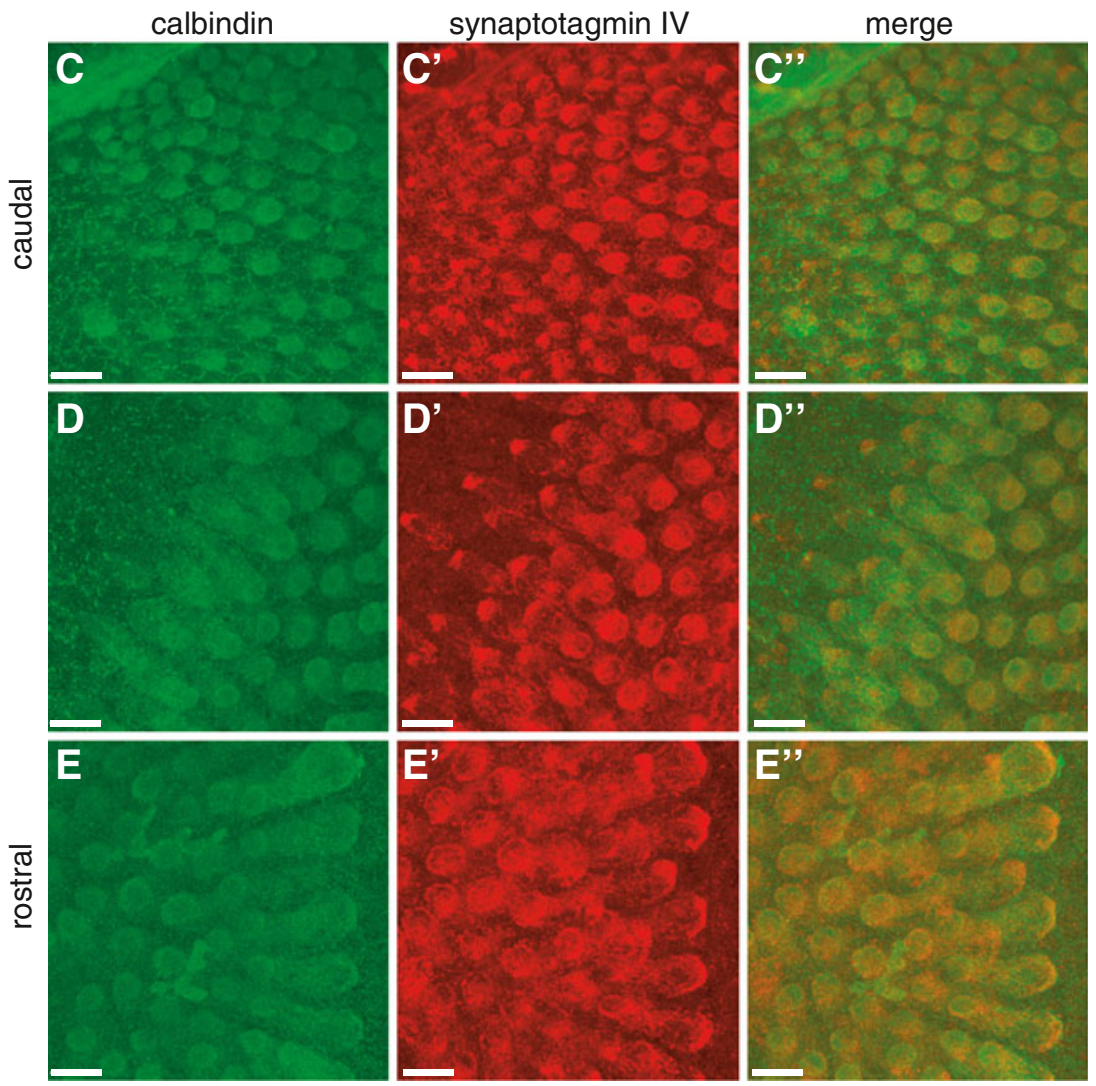

most of the hair cells throughout the epithelium and no gradient in labeling was detected $(p>0.3)$. Calretinin (Fig. 8B, $\mathrm{C}^{\prime}, \mathrm{D}^{\prime}, \mathrm{E}^{\prime}$ ) is strongly expressed only by a small subset of hair cells, located on the lateral, or growing, edge of the sensory epithelium, which showed no calbindin labeling (Fig. 8C", D"). In addition, calretinin antibodies labeled a subset of the calbindin-positive hair cells, although at a much lower level (Fig. 8C', $\mathrm{D}^{\prime \prime}$ ). This mild calretinin signal revealed a clear gradient along the tonotopic axis of the AP epithelium that was statistically significant $(\mathrm{p}<$ $0.03)$ : rostral hair cells were devoid of calretinin (Fig. 8B, E') while caudal hair cells were calretinin positive (Fig. 8B, $\mathrm{C}^{\prime}$ ).

\section{DISCUSSION}

In many vertebrate species, auditory hair cell characteristics (e.g., synaptic structure, innervation patterns) show systematic variation along the tonotopic axis. These variations presumably reflect the different stimuli these cells receive and specific information encoded in their functional outputaction potentials in the auditory nerve. The frog ear is no exception: hair cells from the rostral and caudal portions of the AP differ in several of their properties (see Table 1). Our goal was to characterize similarities and differences between rostral and caudal hair cell exocytosis. 

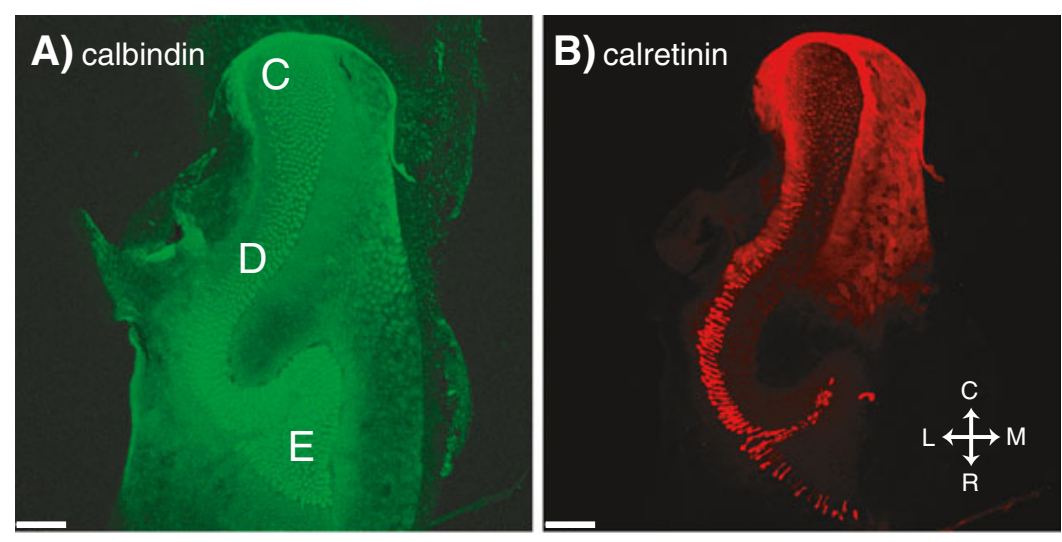

FIG. 8. The general layout of the figure is the same as in Figure 6. Low magnification (10×) images of the AP showing staining for calbindin (A) and calretinin (B). Higher magnification $(63 \times)$ images for three different locations along the AP are given in $(\mathbf{C}),(\mathbf{D})$, and $(\mathbf{E})$. Scale bars: $116 \mu \mathrm{m}(\mathbf{A}, \mathbf{B}) ; 14 \mu \mathrm{m}(\mathbf{C}-\mathbf{E})$.
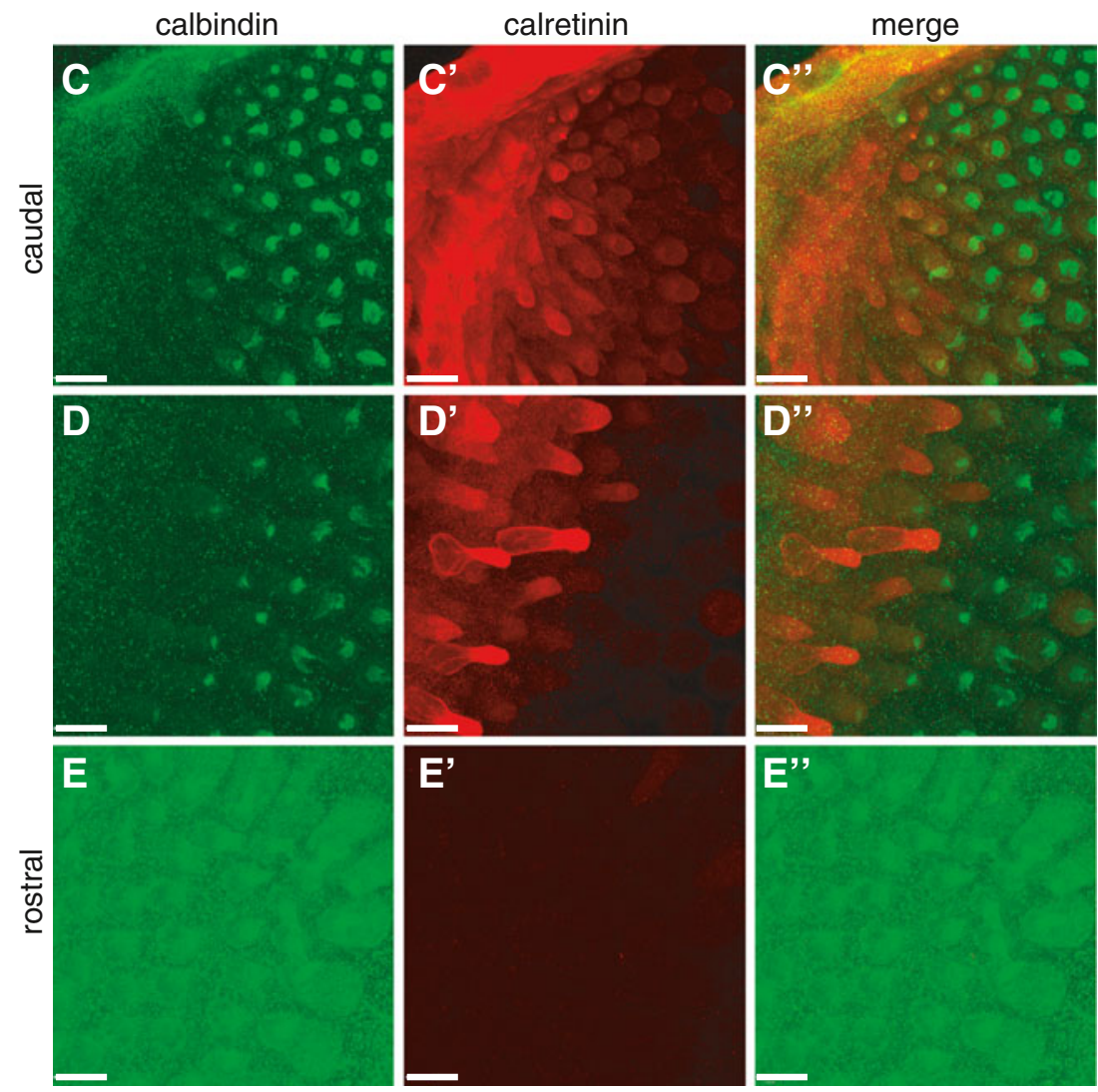

Depolarizing hair cells at either end of the AP elicited rapid increases in cell membrane capacitance (Fig. 1). Consistent with other vertebrate hair cell preparations (Parsons et al. 1994; Moser and Beutner 2000; Spassova et al. 2001; Schnee et al. 2005), these increases are likely due to exocytosis since they were greatly reduced in low calcium and by cadmium (Fig. 2). The capacitance increases were strongly voltage dependent with maximal exocytosis occurring at the peak of the calcium current (Fig. 3A).

\section{Vesicle pools and lack of frequency tuning}

We distinguished three statistically separate phases of exocytosis in rostral and caudal hair cells with depolarizations to both $-50 \mathrm{mV}$ and to $-20 \mathrm{mV}$ : responses to depolarizations (1) shorter than or equal to $50 \mathrm{~ms}$, (2) 100 to $500 \mathrm{~ms}$, and (3) longer than $500 \mathrm{~ms}$ (Fig. 4). This is qualitatively similar to what has been found in other preparations (Nouvian et al. 2006; LoGiudice and Matthews 2007). Morphologically distinct pools of vesicles might subserve these distinct exocytotic phases with a limited docked pool for fast release $(\leq 50 \mathrm{~ms})$ that is followed by slower release from a pool of ribbon-associated vesicles for longer stimuli $(100-500 \mathrm{~ms})$. For sustained release $(>500 \mathrm{~ms})$, the recruitment of additional vesicles is necessary, further slowing exocytosis (Schnee et al. 2005; Rutherford and Roberts 2006; but see Edmonds et al. 2004). Calcium influx increases linearly with stimulus duration and 
TABLE 1

\begin{tabular}{|c|c|c|c|}
\hline \multicolumn{4}{|c|}{ Properties of rostral and caudal hair cells of the frog AP } \\
\hline & Rostral & Caudal & References \\
\hline Frequency range of highest sensitivity & Low $(<\sim 500 \mathrm{~Hz})$ & High $(\sim 500-1,200 \mathrm{~Hz})$ & Lewis et al. 1982 \\
\hline No. of active zones (synaptic sites) & 16/cell & 6/cell & Simmons et al. 1995 \\
\hline Ribbons/synapse & 1 & $1-3$ & Simmons et al. 1995 \\
\hline $\begin{array}{l}\text { Innervation pattern of } \\
\text { afferent nerve fibers }\end{array}$ & $\begin{array}{l}\text { Branched up to } 9 \text { hair } \\
\text { cells/fiber }\end{array}$ & $\begin{array}{l}\text { Unbranched (mostly) at most } \\
\text { a few hair cells/fiber }\end{array}$ & Simmons et al. 1992 \\
\hline Electrical tuning & Yes & No & $\begin{array}{l}\text { Pitchford and } \\
\text { Ashmore }(1987) \\
\text { Smotherman and } \\
\text { Narins }(1999,2000)\end{array}$ \\
\hline Otoferlin, calbindin and parvalbumin & Yes & Yes & This study \\
\hline Calretinin & $\begin{array}{l}\text { No (mostly) some labeling } \\
\text { of lateral edge hair cells }\end{array}$ & Yes & This study \\
\hline Vesicles released/synapse (fast pool) & $\sim 4$ & $\sim 11$ & This study \\
\hline $\mathrm{Ca}^{2+}$ dependence of exocytosis & Linear & Non-linear & This study \\
\hline Frequency dependence of exocytosis & No & No & This study \\
\hline
\end{tabular}

All properties illustrate differences between rostral and caudal hair cells, except for the lack of a frequency dependence of exocytosis in either hair cell type and the presence of otoferlin, calbindin and parvalbumin. Otoferlin and the calcium binding proteins (CaBPs) are found throughout the entire epithelium (see "Results"). The table only shows properties relevant to the discussion in this study and provides only a subset of known differences between hair cells of the rostral and caudal portions of the AP. See also Van Dijk et al. (2011) for comparison of other properties

thus cannot be responsible for the slowing of exocytosis at longer durations (Fig. $4 \mathrm{~A}$ and $\mathrm{B}$ insets). In rostral hair cells, we observed an unusual dip in the $\Delta \mathrm{C}_{\mathrm{m}}$ in response to depolarizations to $-20 \mathrm{mV}$ of intermediate duration (Fig. 4B). This dip was evident from the first recordings and persisted as more recordings were obtained, but it never was statistically significant: responses to $100-500 \mathrm{~ms}$ are indistinguishable from each other. Even so, statistical analysis (see "Methods") indicated three phases of exocytosis in rostral and caudal hair cells. This therefore formed the basis of our group analysis, rather than the more conventional fitting of a series of saturating exponentials.

An exciting discovery in the field of ribbon synapses is the frequency tuning of exocytosis in frog saccular hair cells. A sinusoidal stimulation superimposed onto a weak depolarization elicits more exocytosis at $50 \mathrm{~Hz}$ in hair cells than either at $5 \mathrm{~Hz}$ or $200 \mathrm{~Hz}$ (Rutherford and Roberts 2006). This is especially intriguing since the frog sacculus is particularly sensitive to frequencies of $\sim 50 \mathrm{~Hz}$ (Koyama et al. 1982; Hillery and Narins 1987). We thus investigated whether frequency tuning of exocytosis could contribute to the frequency selectivity of rostral $(100-500 \mathrm{~Hz})$ and caudal hair cells $(500-1,200 \mathrm{~Hz})$. We found that exocytosis depended strictly on calcium influx and was independent of either the amplitude or the frequency of the sinusoidal stimulus (Fig. 5). While AP hair cells were tested over a wide range of frequencies, very sharp tuning to a particular frequency would have been missed. Our data obviously do not rule out the possibility that a subset of hair cells do exhibit frequency selectivity. Also, if all hair cells were tuned to a different frequency the effect would likely average out over recordings from many cells. In addition, exocytosis modulators such as calcium buffers might have been diluted due to the whole-cell recording configuration although this did not affect frequency tuning in the sacculus (Rutherford and Roberts 2006). In summary, we conclude that frequency tuning of exocytosis in the AP is either absent or not as pronounced as in the sacculus and does not likely contribute to tuning of the epithelium.

\section{Differences in exocytosis and CaBP expression between caudal and rostral hair cells}

In all hair cells, the total $\Delta \mathrm{C}_{\mathrm{m}}$ in response to a short depolarization $(\leq 50 \mathrm{~ms})$ to either $-50 \mathrm{mV}$ or $-20 \mathrm{mV}$ command potential was about $3.2 \mathrm{fF}$, or about 71 vesicles (Fig. 4). However, partial EM reconstructions of rostral hair cells have estimated about 16 synaptic ribbon sites while only six for caudal hair cells (Simmons et al. 1995). This indicates that at each synaptic site the fast pool of caudal hair cells is about three times larger (11 vesicles) than the fast pool of rostral hair cells (four vesicles). The larger fast pool implies that caudal hair cells have increased temporal precision of exocytosis (Wittig and Parsons 2008) and achieve greater accuracy of postsynaptic spiking (Buran et al. 2010). Our data are thus consistent with the hypothesis that the high-frequency caudal hair cells are capable of transmitting signals with higher temporal precision than the low-frequency rostral hair cells. This hypothesis is supported by in vivo evidence of reduced fiber response latencies in the caudal AP as compared with the rostral AP in both the Puerto 
Rican treefrog, Eleutherodactylus coqui (Hillery and Narins 1987) and the leopard frog (Hau et al. 2004).

The calcium current amplitudes were not significantly different for rostral and caudal hair cells. Previously, rostral hair cells were shown to have larger peak calcium currents than caudal hair cells (Smotherman and Narins 1999), and the difference in our results may be due to methodology (dissociated cells vs. semi-intact epithelia). As stated previously, rostral hair cells have more synaptic sites, thus, the calcium load at each low frequency rostral synapse is lower than at caudal synapses (rostral-14.1 $\pm 1.2 \mathrm{pA} /$ active zone; caudal$33.5 \pm 3.0 \mathrm{pA}$ /active zone). The positive correlation between frequency and calcium load of the frog AP hair cells contrasts the inverse relationship found in the turtle (Schnee et al. 2005). Furthermore, the lowfrequency rostral hair cells have the greater number of ribbons per hair cell and also the larger calculated release area. The gradient is different in the chick basilar papilla where the high frequency tall hair cells had the largest synaptic areas and currents (MartinezDunst et al. 1997). This frequency, peak calcium current and synaptic area correlation is also true in the turtle (Schnee et al. 2005).

Another difference, albeit subtle, is the calcium dependence of exocytosis [linear for low frequency rostral hair cells (Fig. 3B) and non-linear for highfrequency caudal hair cells (Fig. 3C)]. A linear relationship was previously found for the medial portion of the AP (Keen and Hudspeth 2006; Cho et al. 2011), where hair cells exhibit intermediate properties (Smotherman and Narins 1999). The relationship between hair cell frequency response and calcium dependence of exocytosis is the inverse of that found in the gerbil cochlea [linear for hair cells from the cochlear base and non-linear for cells from the apex (Johnson et al. 2008)]. We speculate that this is consistent with the fact that auditory nerve fibers of rodents exhibit a preponderance of highfrequency tuning, matching the high-frequency components of their communication signals (Evans 1972; Schmiedt 1989; el Barbary 1991). In contrast, the majority of auditory nerve fibers in many frog species are tuned to low frequencies presumably reflecting their universal sensitivity to low-level substrate vibrations (Zakon and Wilczynski 1988; ChristensenDalsgaard and Narins 1993). However, further studies using changes in extracellular calcium (for medial AP see Cho et al. 2011) and calcium uncaging approaches will be necessary to corroborate and explore this difference in more detail.

The differences in calcium dependence might be due to the presence of a protein with "linearizing properties". Both otoferlin, a putative calcium sensor for exocytosis in hair cells (Roux et al. 2006; but see Johnson et al. 2010), and SytIV have been shown to be necessary for the linear calcium dependence of exocytosis (Dulon et al. 2009; Beurg et al. 2010; Johnson et al. 2010; reviewed in Gregory and Quiñones 2011). Using immunohistochemistry, we did not detect differences in the expression pattern of either otoferlin or SytIV along the tonotopic axis of the frog AP (Figs. 6 and 7). While the antibody against otoferlin has been shown to be highly specific in frog (Goodyear et al. 2010), it seems possible that the SytIV antibody, while specific in rodents (Johnson et al. 2010), might crossreact with Syt isoforms and even other proteins in frog, thereby obscuring any SytIVspecific gradients. The linear dependence of exocytosis on calcium influx could also result from vesicle fusion controlled by calcium "nanodomains", rather than "microdomains" (Augustine et al. 2003). This may suggest tight coupling of calcium channels with vesicles for rostral and looser coupling for caudal hair cells. Consistent with the notion of nanodomains, command voltages to $-50 \mathrm{mV}$ and to $0 \mathrm{mV}$ induce similar $\mathrm{Q}_{\mathrm{Ca}}{ }^{2+}$, yet $\Delta \mathrm{C}_{\mathrm{m}}$ at $-50 \mathrm{mV}$ (large single channel current but few open channels) is larger than $\Delta \mathrm{C}_{\mathrm{m}}$ at $0 \mathrm{mV}$ (small single channel current but many open channels) suggesting nanodomain coupling. However, since this was observed for both rostral and caudal hair cells, a difference in coupling is unlikely to explain the difference in linearity. We speculate that nanodomain coupling in "auditory" hair cells of the frog amphibian papilla is similar to mammalian cochlear inner hair cells (Brandt et al. 2005; Goutman and Glowatzki 2007), while exocytosis in the "vestibular" frog sacculus (Roberts et al. 1990; Roberts 1994) and the mammalian utricle (Dulon et al. 2009) is controlled by overlapping calcium channel microdomains. Indeed, changing external calcium in the medial portion of the AP resulted in linear changes in $\Delta \mathrm{C}_{\mathrm{m}}$ (Cho et al. 2011) for short depolarizing pulses supporting the notion that the auditory AP has nanodomain coupling. At the rostral and caudal ends of the AP, additional experiments changing external calcium concentrations and using caged calcium will be necessary to clearly distinguish between these interpretations. Finally, the linear calcium dependence could result from summation across active zones with different sensitivities (Heil and Neubauer 2010), suggesting that active zones in rostral hair cells are more heterogeneous.

While two major CaBPs, calbindin (Fig. 8) and parvalbumin (data not shown), expressed strongly throughout the epithelium, another, calretinin, expressed strongly in calbindin-negative lateral-edge hair cells along the entire epithelium (Fig. 8). The lateral edge of the AP has been proposed as a growth zone of the macula because hair cells gradually fade into undifferentiated cells (Geisler et al. 1964) and because the hair bundle type found in this region is 
immature ( $\mathrm{Li}$ and Lewis 1974). Therefore, the strongly calretinin-labeled calbindin-negative cells might be immature and newly developing hair cells. In addition, evidence from the sacculus suggests that brightly labeled calretinin cells may simply be a distinct subtype (Edmonds et al. 2000; Rutherford and Roberts 2009). Furthermore, of the majority of hair cells which were calbindin positive, only caudal but not rostral hair cells were mildly calretinin positive. The fast on-rates of calretinin help to maintain temporal fidelity of the calcium signal during repetitive stimulation (Schwaller 2009), which preserves the representation of high-frequency stimuli. This property is more important for the high-frequency caudal hair cells. The tonotopic distribution of calretinin indicates a novel molecular difference between rostral and caudal hair cells with relevance for exocytosis and cell signaling.

The observed rostro-caudal differences indicate functional adaptations at the two ends of the AP. Frogs need to respond to small amplitude, lowfrequency substrate-borne vibrations and low-frequency, rostral nerve fibers are thought to be more sensitive than caudal fibers (Zelick and Narins 1985; Narins 1987; Stiebler and Narins 1990; but see Feng et al. 1975). The lowered nerve thresholds, i.e., increased sensitivity, found in the rostral portion of the AP may be due to the rostral hair cell linear response to low-intensity signals which would serve to extend the range of the rostral AP fibers to include lowamplitude signals. Rostral hair cells have distinct properties that contribute to signal detection: (1) linear calcium dependence of exocytosis (Fig. 3), (2) electrical resonance (Pitchford and Ashmore 1987; Ospeck et al. 2001), and (3) spatial integration across the output of multiple rostral AP hair cells due to the increased terminal branching of their afferent fibers (Simmons et al. 1992). Just as the functional adaptations in rostral hair cells subserve physiological demands, a similar case can be made for adaptations in caudal hair cells. The short auditory-nerve latencies (Hillery and Narins 1987; Hau et al. 2004) and sharpness of tuning, i.e., frequency selectivity (Stiebler and Narins 1990; but see Narins 1987), indicate a high temporal acuity for the higher frequency caudal hair cells. This might be aided in caudal hair cells by (1) calretinin expression (Fig. 8), (2) the larger number of vesicles released per synapse (Figs. 3, 4, and 5 ), and (3) minimal convergence of afferent coding due to reduced afferent nerve fiber branching (Lewis et al. 1982; Simmons et al. 1992). All these properties could serve to retain the temporal information of an incoming stimulus. Thus, the anuran ear, which shares many characteristics with the mammalian ear, also employs distinct strategies tailored to its ethological needs.

\section{ACKNOWLEDGMENTS}

We thank Dr. Matthew J. Mason and Dr. S.W.F. Meenderink for critical review of the manuscript. We are grateful to Taishi Toyoaki for providing effective and efficient customized analysis software. We thank Dr. Dwayne Simmons for use of his confocal microscope and for providing the myosin VI antibody. We also thank Dr. Jeffrey Corwin for providing his HCS-1 antibody and Dr. Marlies Knipper for sharing synaptotagmin IV antibodies and appreciate Christoph Franz for providing Knipper lab protocols. We would also like to thank Dr. Frederick D. Gregory for his assistance in getting this project off the ground. This work is supported by NIH grants no. DC00222 to PMN and DC007678 to FES.

\section{REFERENCES}

Augustine GJ, Santamaria F, Tanaka K (2003) Local calcium signaling in neurons. Neuron 40:331-346

Bernard C, Ferrary E, Sterkers O (1986) Production of endolymph in the semicircular canal of the frog Rana esculenta. J Physiol 371:17-28

Beurg M, Michalski N, Safieddine S, Bouleau Y, Schneggenburger R, Chapman ER, Petit C, Dulon D (2010) Control of exocytosis by synaptotagmins and otoferlin in auditory hair cells. J Neurosci 30:13281-13290

Brandt A, Khimich D, Moser T (2005) Few CaV1.3 channels regulate the exocytosis of a synaptic vesicle at the hair cell ribbon synapse. J Neurosci 25:11577-11585

Buran BN, Strenzke N, Neef A, Gundelfinger ED, Moser T, Liberman MC (2010) Onset coding is degraded in auditory nerve fibers from mutant mice lacking synaptic ribbons. J Neurosci 30:75877597

Cho S, Li GL, von Gersdorff H (2011) Recovery from short-term depression and facilitation is ultrafast and $\mathrm{Ca}^{2+}$ dependent at auditory hair cell synapses. J Neurosci 31:5682-5692

Christensen-Dalsgaard J, Narins PM (1993) Sound and vibration sensitivity of VIIIth nerve fibers in the frogs Leptodactylus albilabris and Rana pipiens pipiens. J Comp Physiol A 172:653662

Dodge FA JR, RAhamimoff R (1967) Co-operative action a calcium ions in transmitter release at the neuromuscular junction. J Physiol 193:419-432

Dulon D, Safieddine S, Jones SM, Petit C (2009) Otoferlin is critical for a highly sensitive and linear calcium-dependent exocytosis at vestibular hair cell ribbon synapses. J Neurosci 29:10474-10487

Edmonds B, Reyes R, Schwaller B, Roberts WM (2000) Calretinin modifies presynaptic calcium signaling in frog saccular hair cells. Nat Neurosci 3:786-790

Edmonds BW, Gregory FD, Schweizer FE (2004) Evidence that fast exocytosis can be predominantly mediated by vesicles not docked at active zones in frog saccular hair cells. J Physiol 560:439-450

EL BARbary A (1991) Auditory nerve of the normal and jaundiced rat. I. Spontaneous discharge rate and cochlear nerve histology. Hear Res 54:75-90

Evans EF (1972) The frequency response and other properties of single fibres in the guinea-pig cochlear nerve. J Physiol 226:263-287

FARAHBAKHSH NA, NARINS PM (2006) Slow motility in hair cells of the frog amphibian papilla: $\mathrm{Ca}^{2+}$-dependent shape changes. Hear Res 212:140-159

Feng AS, Narins PM, Capranica RR (1975) Three populations of primary auditory fibers in bullfrog (Rana catesbeiana)-their 
peripheral origins and frequency sensitivities. J Comp Physiol 100:221-229

Fettiplace R, Fuchs PA (1999) Mechanisms of hair cell tuning. Annu Rev Physiol 61:809-834

Gale JE, Meyers JR, Corwin JT (2000) Solitary hair cells are distributed throughout the extramacular epithelium in the bullfrog's saccule. J Assoc Res Otolaryngol 1:172-182

Geisler CD, VAnBergeijK WA, Frishkopf LS (1964) The inner ear of the bullfrog. J Morphol 114:43-57

Gentet LJ, Stuart GJ, Clements JD (2000) Direct measurement of specific membrane capacitance in neurons. Biophys J 79:314-320

Goodyear RJ, Legan PK, Christiansen JR, Xia B, Korchagina J, Gale JE, Warchol ME, Corwin JT, Richardson GP (2010) Identification of the hair cell soma-1 antigen, HCS-1, as otoferlin. J Assoc Res Otolaryngol 11:573-586

Goutman JD, Glowatzki E (2007) Time course and calcium dependence of transmitter release at a single ribbon synapse. Proc Natl Acad Sci USA 104:16341-16346

Gregory FD, QuiÑones PM (2011) Deciphering the roles of $\mathrm{C}_{2-}$ domain-containing proteins (synaptotagmins and otoferlin) in the inner ear. J Neurosci 31:4765-4767

Hau LW, Simmons DD, Narins PM (2004) Frequency-dependence of auditory-nerve latency in the northern leopard frog, Rana pipiens pipiens. In: Abstr. 27th ARO Res. Mtg. 336

Heil P, Neubauer H (2010) Summing across different active zones can explain the quasi-linear $\mathrm{Ca}^{2+}$-dependencies of exocytosis by receptor cells. Front Synaptic Neurosci 2:1-15

Hillery CM, NARINS PM (1987) Frequency and time domain comparison of low-frequency auditory fiber responses in two anuran amphibians. Hear Res 25:233-248

Johnson SL, Thomas MV, Kros CJ (2002) Membrane capacitance measurement using patch clamp with integrated self-balancing lock-in amplifier. Pflugers Arch 443:653-663

Johnson SL, Forge A, Knipper M, Munkner S, Marcotti W (2008) Tonotopic variation in the calcium dependence of neurotransmitter release and vesicle pool replenishment at mammalian auditory ribbon synapses. J Neurosci 28:7670-7678

Johnson SL, Franz C, Knipper M, Marcotti W (2009) Functional maturation of the exocytotic machinery at gerbil hair cell ribbon synapses. J Physiol 587:1715-1726

Johnson SL, Franz C, Kuhn S, Furness DN, Ruttiger L, Munkner S, Rivolta MN, Seward EP, Herschman HR, Engel J, Knipper M, MARсоттI W (2010) Synaptotagmin IV determines the linear $\mathrm{Ca}^{2+}$ dependence of vesicle fusion at auditory ribbon synapses. Nat Neurosci 13:45-52

Keen EC, Hudspeth AJ (2006) Transfer characteristics of the hair cell's afferent synapse. Proc Natl Acad Sci USA 103:5537-5542

Koyama H, Lewis ER, Leverenz EL, Baird RA (1982) Acute seismic sensitivity in the bullfrog ear. Brain Res 250:168-172

Lenzi D, Runyeon JW, Crum J, Ellisman MH, Roberts WM (1999) Synaptic vesicle populations in saccular hair cells reconstructed by electron tomography. J Neurosci 19:119-132

LEWIS ER (1976) Surface morphology of the bullfrog amphibian papilla. Brain Behav Evol 13:196-215

LEWIS ER, NARINS PM (1999) The acoustic periphery of amphibians: anatomy and physiology. In: Comparative hearing: fish and amphibians. Springer, New York, pp 101-154

Lewis ER, Baird RA, Leverenz EL, Koyama H (1982) Inner ear: dye injection reveals peripheral origins of specific sensitivities. Science 215:1641-1643

LI CW, LEWIS ER (1974) Morphogenesis of auditory receptor epithelia in the bullfrog. Scan Electron Microsc 1974:791-798

Li GL, Keen E, ANdor-Ardo D, Hudspeth AJ, von GersdorfF H (2009) The unitary event underlying multiquantal EPSCs at a hair cell's ribbon synapse. J Neurosci 29:7558-7568

LoGiudice L, Matthews G (2007) Endocytosis at ribbon synapses. Traffic 8:1123-1128
Martinez-Dunst C, Michaels RL, Fuchs PA (1997) Release sites and calcium channels in hair cells of the chick's cochlea. J Neurosci 17:9133-9144

Meyer AC, Frank T, Khimich D, Hoch G, Riedel D, Chapochnikov NM, Yarin YM, Harke B, Hell SW, Egner A, Moser T (2009) Tuning of synapse number, structure and function in the cochlea. Nat Neurosci 12:444-453

Moser T, Beutner D (2000) Kinetics of exocytosis and endocytosis at the cochlear inner hair cell afferent synapse of the mouse. Proc Natl Acad Sci USA 97:883-888

NARINS PM (1987) Coding of signals in noise by amphibian auditory nerve fibers. Hear Res 26:145-154

Nouvian R, Beutner D, Parsons TD, Moser T (2006) Structure and function of the hair cell ribbon synapse. J Membr Biol 209:153-165

Ospeck M, Eguiluz VM, Magnasco MO (2001) Evidence of a Hopf bifurcation in frog hair cells. Biophys J 80:2597-2607

Parsons TD, Lenzi D, Almers W, Roberts WM (1994) Calciumtriggered exocytosis and endocytosis in an isolated presynaptic cell: capacitance measurements in saccular hair cells. Neuron $13: 875-883$

PitchFord S, Ashmore JF (1987) An electrical resonance in hair cells of the amphibian papilla of the frog Rana temporaria. Hear Res 27:75-83

RoBerTs WM (1993) Spatial calcium buffering in saccular hair cells. Nature 363:74-76

ROBERTS WM (1994) Localization of calcium signals by a mobile calcium buffer in frog saccular hair cells. J Neurosci 14:32463262

Roberts WM, Jacobs RA, Hudspeth AJ (1990) Colocalization of ion channels involved in frequency selectivity and synaptic transmission at presynaptic active zones of hair cells. J Neurosci 10:36643684

Robles L, RUgGero MA (2001) Mechanics of the mammalian cochlea. Physiol Rev 81:1305-1352

Roux I, Safieddine S, Nouvian R, Grati M, Simmler MC, Bahloul A, Perfettini I, Le Gall M, Rostaing P, Hamard G, Triller A, Avan P, Moser T, Petit C (2006) Otoferlin, defective in a human deafness form, is essential for exocytosis at the auditory ribbon synapse. Cell 127:277-289

Rutherford MA, RoberTs WM (2006) Frequency selectivity of synaptic exocytosis in frog saccular hair cells. Proc Natl Acad Sci USA 103:2898-2903

RUtHERFord MA, Roberts WM (2009) Spikes and membrane potential oscillations in hair cells generate periodic afferent activity in the frog sacculus. J Neurosci 29:10025-10037

SCHMIEDT RA (1989) Spontaneous rates, thresholds and tuning of auditory-nerve fibers in the gerbil: comparisons to cat data. Hear Res 42:23-35

Schnee ME, Lawton DM, Furness DN, Benke TA, Ricci AJ (2005) Auditory hair cell-afferent fiber synapses are specialized to operate at their best frequencies. Neuron 47:243-254

SchWAller B (2009) The continuing disappearance of "pure" $\mathrm{Ca}^{2+}$ buffers. Cell Mol Life Sci 66:275-300

Simmons DD, Bertolotto C, Narins PM (1992) Innervation of the amphibian and basilar papillae in the leopard frog: reconstructions of single labeled fibers. J Comp Neurol 322:191-200

Simmons DD, Bertolotto C, Narins PM (1994) Morphological gradients in sensory hair cells of the amphibian papilla of the frog, Rana pipiens pipiens. Hear Res 80:71-78

Simmons DD, Bertolotto C, Leong M (1995) Synaptic ultrastructure within the amphibian papilla Rana pipiens pipiens: rostrocaudal differences. Audit Neurosci 1:183-193

Smotherman MS, Narins PM (1999) The electrical properties of auditory hair cells in the frog amphibian papilla. J Neurosci 19:5275-5292

Solsona C, Innocenti B, Fernandez JM (1998) Regulation of exocytotic fusion by cell inflation. Biophys J 74:1061-1073 
Spassova M, Eisen MD, Saunders JC, Parsons TD (2001) Chick cochlear hair cell exocytosis mediated by dihydropyridinesensitive calcium channels. J Physiol 535:689-696

Stiebler IB, Narins PM (1990) Temperature-dependence of auditory nerve response properties in the frog. Hear Res 46:63-81

Van Dijk P, Mason MJ, Schoffelen RL, Narins PM, Meenderink SWF (2011) Mechanics of the frog ear. Hear Res 273:46-58

WitTig JH JR, PARsons TD (2008) Synaptic ribbon enables temporal precision of hair cell afferent synapse by increasing the number of readily releasable vesicles: a modeling study. J Neurophysiol 100:1724-1739

ZAKON HH, WiLCZYNSKI W (1988) The physiology of the anuran VIIIth nerve. In: Fritzsch B, Wolkowiak W, Ryan MJ, Wilczynski $\mathrm{W}$, Hetherington $\mathrm{T}$ (eds) The evolution of the amphibian auditory system. Wiley, New York, pp 125-155

Zelick R, NARins PM (1985) Temporary threshold shift, adaptation, and recovery characteristics of frog auditory nerve fibers. Hear Res 17:161-176 